\title{
Bioactivity of Piper extracts on Tuta absoluta (Lepidoptera: Gelechiidae) in tomato
}

\author{
Elaine Ferrari de Brito(1), Edson Luiz Lopes Baldin(1), Roney de Carvalho Macedo Silva(1), \\ Leandro do Prado Ribeiro(2) and José Djair Vendramim ${ }^{(3)}$
}

\begin{abstract}
(1)Universidade Estadual Paulista, Faculdade de Ciências Agronômicas, Campus de Botucatu, Rua José Barbosa de Barros, no 1.780, CEP 18610-307 Botucatu, SP, Brazil. E-mail: elaine.ferrari@fca.unesp.br, elbaldin@fca.unesp.br, roneykk@hotmail.com(2)Empresa de Pesquisa Agropecuária e Extensão Rural de Santa Catarina, Centro de Pesquisa para Agricultura Familiar, Rua Servidão Ferdinando Tusset, s/no, São Cristóvão, CEP 89801-970 Chapecó, SC, Brazil. E-mail: leandroribeiro@epagri.sc.gov.br (3)Universidade de São Paulo, Escola Superior de Agricultura Luiz de Queiroz, Avenida Pádua Dias, no 11, CEP 13418-900 Piracicaba, SP, Brazil. E-mail: jdvendra@usp.br
\end{abstract}

\begin{abstract}
The objective of this work was to evaluate the bioactivity of ethanolic leaf extracts from four species of the genus Piper against the tomato leafminer Tuta absoluta (Lepidoptera: Gelechiidae) under laboratory conditions. The evaluated species were: P. amalago var. medium, P. glabratum, P. mikanianum, and P. mollicomum. In the initial screening assay (extract concentration of $2,000 \mathrm{mg} \mathrm{L}^{-1}$ ), all tested extracts caused significant larval mortality, particularly the extract of $P$. amalago var. medium; however, no extracts reduced the weight of the surviving larvae. The extract from P. amalago var. medium at the concentration of $1,011 \mathrm{mg} \mathrm{L}^{-1}$ caused a significant lengthening of the larval and pupal stages. The ethanolic leaf extract of $P$. amalago var. medium is promising for the control of T. absoluta larvae in tomato, since it exhibits acute toxicity toward these caterpillars at the concentration of 2,000 $\mathrm{mg} \mathrm{L}^{-1}$ and affects the insect's development by reducing its survival and lengthening the larval and pupal stages.
\end{abstract}

Index terms: Piper amalago var. medium, botanical extracts, piperamides, tomato leafminer.

\section{Bioatividade de extratos de Piper sobre Tuta absoluta (Lepidoptera: Gelechiidae) em tomateiro}

\begin{abstract}
Resumo - O objetivo deste trabalho foi avaliar a bioatividade de extratos etanólicos de folhas de quatro espécies do gênero Piper sobre a traça-do-tomateiro Tuta absoluta (Lepidoptera: Gelechiidae), em condições de laboratório. As espécies avaliadas foram: P. amalago var. medium, P. glabratum, P. mikanianum e P. mollicomum. Na triagem inicial (concentração do extrato de $2.000 \mathrm{mg} \mathrm{L}^{-1}$ ), todos os extratos testados causaram significativa mortalidade larval, principalmente o extrato de P. amalago var. medium; entretanto, nenhum extrato ocasionou redução do peso das lagartas sobreviventes. O extrato de P. amalago var. medium na concentração de $1.011 \mathrm{mg} \mathrm{L}^{-1}$ promoveu alongamento significativo da fase larval e pupal. $\mathrm{O}$ extrato etanólico de folhas de $P$. amalago var. medium é promissor no controle de lagartas de T. absoluta em tomateiro, pois exibe toxicidade aguda a lagartas na concentração de $2.000 \mathrm{mg} \mathrm{L}^{-1}$ e afeta o desenvolvimento do inseto, ao reduzir a sua sobrevivência e alongar as fases larval e pupal.
\end{abstract}

Termos para indexação: Piper amalago var. medium, extratos botânicos, piperamidas, traça-do-tomateiro.

\section{Introduction}

The tomato leafminer Tuta absoluta (Meyrick) (Lepidoptera: Gelechiidae) is native to South America. The species is present in the main producing countries of tomato [Solanum lycopersicum (L.)] (Solanaceae) in Latin America and is currently gaining status as a major threat to the worldwide production of this fruit due to the recent occurrence of tomato leafminer in European production centers (European and Mediterranean Plant Protection Organization, 2005; Desneux et al., 2010).
In Brazil, T. absoluta is one of the key insect pests of the tomato crop, reducing productivity up to $100 \%$ (Souza $\&$ Reis, 2000). The damage is caused by the larvae of the insect, which feed and grow on soft tissues, such as leaves, shoots, and fruits from the aerial part of the plant, at any stage of tomato growth.

Although chemical control has been the main method used against $T$. absoluta in South America, the low efficiency of the active ingredients against this insect has been reported since the 1990s (Campos et al., 2014). Furthermore, the intensive use of synthetic 
chemicals as the sole strategy for insect control together with insect traits, such as high reproductive potential (10-12 generations per year) and mining habit, has favored the selection of insects resistant to the different active ingredients, especially pyrethroids, avermectins, cartap, and diamides (Lietti et al., 2005; Silva et al., 2011; Roditakis et al., 2015). Although the Brazilian Ministry of Agriculture, Livestock and Food Supply requires an efficiency higher than $80 \%$ for the registration of a new formulation, the continued use of certain active ingredient leads to the selection of resistant populations (selection pressure), which has already been shown in some studies developed in the field, with populations of T. absoluta resistant to avermectin, pyrethroids, and cartap (Lietti et al., 2005; Silva et al., 2011). The high biotic potential of this species (10-12 generations per year) leads to an increase in spraying frequency, reaching 40 applications per crop cycle in growing conditions in Brazil, which accelerates the evolution of resistance. In Europe, where T. absoluta was recently introduced, there have been reports of populations of this insect with high frequency of individuals containing alleles that confer resistance to pyrethroids (Haddi et al., 2012; Roditakis et al., 2013). Therefore, researches on alternative management and new active compounds are necessary.

Alternative pest management, aiming at the sustainability of production systems, has been investigated, resulting in new perspectives for studies with allelochemicals and their application in the formulation of botanical insecticides (Cantrell et al., 2012). Various derivatives of vegetable origin, especially in the form of extracts or essential oils, have been suggested as alternatives to synthetic pesticides (Philogène \&Vincent, 2005). One of the most studied species in recent decades is neem (Azadirachta indica A. Juss) (Meliaceae) (Morgan, 2004), and several commercial formulations with it are now available worldwide.

Under tropical and subtropical conditions, Piperaceae also constitute a promising source of botanical insecticides due to their great abundance (Dyer \& Palmer, 2004) and diversity of allelochemicals with insecticidal/insectistatic properties (Scott et al., 2008). In Brazil, there are approximately 450 species of Piperaceae, mostly belonging to the genus Piper (Yuncker, 1975), and bioassay-guided Piperaceae studies have been conducted to identify species with insecticidal potential (Scott et al., 2005, 2008). Moreover, there are formulations of Piperaceae derivatives already in registration process in Brazil (Brasil, 2009). Piperamides are among the major classes of compounds found in species of the genus Piper, and these compounds offer dual biological activity on insects, including neurotoxic effects and effects on lipid metabolism (Dyer \& Palmer, 2004), an important characteristic for the management of resistant populations (Scott et al., 2004).

The objective of this work was to evaluate the bioactivity of ethanolic leaf extracts from four species of the genus Piper against the tomato leafminer T. absoluta under laboratory conditions.

\section{Materials and Methods}

A stock rearing of T. absoluta was established using larvae collected in commercial tomato fields, in the municipality of Botucatu, in the state of São Paulo, Brazil $\left(22^{\circ} 85^{\prime} \mathrm{S}, 48^{\circ} 26^{\prime} \mathrm{W}\right)$. The stock was maintained in laboratory conditions $\left(25 \pm 2^{\circ} \mathrm{C}, 65 \pm 10 \%\right.$ relative humidity, and 14-hour photophase). Leaves of 'Santa Clara' commercial tomato were used to feed the insect during the larval stage, and a solution of $10 \%$ $(\mathrm{p} / \mathrm{v})$ honey during the adult stage. The insects were maintained in aluminum cages $(40 \times 40 \times 60 \mathrm{~cm})$ with an antiaphid mesh on the sides and acrylic at the front and on the top.

The Piperaceae plants used were collected in the campus of Escola Superior de Agricultura Luiz de Queiroz (Esalq) of Universidade de São Paulo in the municipality of Piracicaba, in the state of São Paulo, Brazil (22 $\left.42^{\prime} 52,7^{\prime \prime S}, 47^{\circ} 37^{\prime} 46^{\prime \prime} \mathrm{W}\right)$, on November $15^{\text {th }}$ 2012. A voucher of each studied specimen was deposited in the herbarium of Esalq, under the following reference numbers: Piper amalago var. medium (121200); P. glabratum (121206); P. mikanianum (121201); and P. mollicomum (121202).

To prepare the extracts, the leaves collected from adult plants were oven-dried at $40^{\circ} \mathrm{C}$ for $48-72$ hours. Subsequently, the leaves were separately milled in a knife mill to obtain a powder and then stored in a refrigerator at $-20^{\circ} \mathrm{C}$ in sealed glass containers until use; storage time was less than 14 days. The extractions were carried out by cold maceration using 99.5\% ethanol as a solvent in a 1:5 (v/w) ratio. For this, the macerated material was kept for 3 days in the solvent and then filtered through filter paper. Any remaining 
residue was resuspended in the solvent, and the process was repeated four times. The solvent present in the filtered solution was eliminated using a rotary evaporator at a temperature of $40^{\circ} \mathrm{C}$ and a pressure of $600 \mathrm{~mm} \mathrm{Hg}$. After total evaporation of the solvent in an air-flow chamber, the obtained residue was weighed to determine the yield of extraction. After that, the extracts were kept under refrigeration at $-20^{\circ} \mathrm{C}$ until use in the bioassays.

All assays were conducted in a completely randomized design in an acclimated room at $25 \pm 2{ }^{\circ} \mathrm{C}$, $65 \pm 10 \%$ relative humidity, and 14 -hour photophase.

For the selection of the most promising treatment, leaf extracts from $P$. amalago var. medium, $P$. glabratum, $P$. mikanianum, and $P$. mollicomum were tested at the concentration of 2,000 $\mathrm{mg} \mathrm{L}^{-1}$, with the negative control consisting of the acetone solvent used to solubilize the extracts. Seven replicates were used per treatment, and each replicate (experimental unit) consisted of four plates, each containing four newly-hatched larvae for a total of 112 larvae per treatment.

The extracts were applied on tomato leaves detached from the upper third of approximately 30-day-old potted plants cultivated in greenhouse. The extracts were applied with the aid of an Arprex microatomizer, model 5A (Arprex, Mogi das Cruzes, SP, Brazil), coupled to a pneumatic pump and adjusted to provide a pressure of $0.5 \mathrm{kgf} \mathrm{cm}^{-2}$; the extract was sprayed until the excess started dripping off the leaves. After drying the waste $(\sim 30 \mathrm{~min})$, the leaflets were placed separately in plastic Petri dishes $(96 \mathrm{~mm}$ in diameter and $21 \mathrm{~mm}$ in height) and infested with five newly-hatched larvae. To maintain turgor, the petiole of each leaflet was wrapped in moistened cotton wool. Larval mortality was assessed daily for six days with the aid of a binocular stereoscopic microscope. After this period, the weight of the surviving larvae was also evaluated.

The extract that caused the highest average mortality was selected for further studies, and concentration-response curves were evaluated to estimate the concentrations necessary to cause 50 and $90 \%$ mortality $\left(\mathrm{LC}_{50}\right.$ and $\mathrm{LC}_{90}$, respectively) of the individuals of the exposed population. Preliminary tests were conducted to estimate the concentrations that could cause mortality levels of $95 \%$ and close to the control. Based on this, six concentrations to be tested, ranging from $500-7,000 \mathrm{mg} \mathrm{L}^{-1}$, were established using the procedure proposed by Finney (1971). The experimental procedures, sample units, number of replicates, and exposure times were the same as those used for initial screening.

The sublethal effects of the extract of $P$. amalago var. medium at the estimated concentration $\left(\mathrm{LC}_{50}\right)$ were evaluated on T. absoluta. Tomato leaves detached from the upper third of approximately 30-day-old plants were used. The extracts were sprayed following the same procedures described for initial screening. The acetone solvent used for the solubilization of the extract was used as a control. After drying the residue ( $\sim 30 \mathrm{~min})$, the petiole of each leaf was placed in a $50-\mathrm{mL}$ glass tube containing distilled water. The leaves were then infested with six newly-hatched caterpillars and placed inside cages consisting of a rectangular polystyrene base $(20 \times 10 \times 3 \mathrm{~cm})$ and a transparent cylindrical plastic arena $(11 \mathrm{~cm}$ in diameter and $27 \mathrm{~cm}$ in height); the arena was covered with voile to prevent the caterpillars from escaping. Twenty replicates for each treatment were used, totalizing 120 larvae per treatment. Larval mortality was assessed daily until the pre-pupal stage; subsequently, the larvae were placed separately in Petri dishes. The insects were monitored throughout their lifecycle to obtain the following variables: duration (days) of larval and pupal stages, larval mortality, pupal weight, and sex ratio.

The estimates of lethal concentrations were analyzed by a binomial function with the complementary log-log link (gompit model) using the Probit procedure of the SAS software, version 9.2 (SAS Institute, Cary, $\mathrm{NC}$, USA). For the analysis of the other bioassays, generalized linear models (GLMs) belonging to the exponential family of distributions (Nelder \& Wedderburn, 1972) were used. The goodness of fit of the data to the models was verified through the use of a half-normal probability plot with a simulation envelope (Hinde \& Demétrio, 1998). When significant differences were found between the treatments, multiple comparisons were performed by Tukey's post hoc test, at $5 \%$ probability, using the general linear hypothesis test (glht) function from the multcomp package with adjustment for $\mathrm{p}$ values. All analyses were performed using the $\mathrm{R}$ statistical software, version 2.15.1 (R Development Core Team, 2012).

\section{Results and Discussion}

The yield of the obtained extracts varied with the plant species, and the highest yield was obtained from 
the extract of $P$. mikanianum $(7.97 \%)$, followed by the extracts of $P$. mollicomum (6.98\%), P. glabratum (6.46\%), and $P$. amalago var. medium (6.10\%). Although the yield of the leaf extracts can be considered high using ethanol (bipolar solvent), further studies are required to optimize the extraction method of the promising extracts, taking into account the economic aspect of the process and its adequacy to the concepts of environmental sustainability and green chemistry (Ribeiro et al., 2014).

With the exception of the ethanolic leaf extract of $P$. mollicomum, the other extracts caused significant mortality in $T$. absoluta larvae (Table 1). However, although showing acute toxicity, neither of the extracts caused a significant reduction in the weight of the surviving larvae by the sixth day (144 hours) of exposure. Other studies have also shown the potential of Piper species as a source of botanical insecticides, with bioactivity on other pests of agricultural importance, such as: Spodoptera frugiperda (J.E. Smith) (Lepidoptera: Noctuidae) (Alves et al., 2014; Murillo et al., 2014); Spodoptera litura (F.) (Lepidoptera: Noctuidae) (Kitayama et al., 2013); Mythimna separata (Walker) (Lepidoptera: Noctuidae) (Qu et al., 2013); Diatraea saccharalis (Fabr.) (Lepidoptera: Pyralidae) (Debonsi et al., 2008); Malacosoma disstria Hübner (Lepidoptera: Lasiocampidae); Lymantria dispar (L.) (Lepidoptera: Lymantriidae) (Scott et al., 2007); and Anticarsia gemmatalis Hübner (Lepidoptera: Noctuidae) (Navickiene et al., 2007). However, this is the first study to report the bioactivity of $P$. amalago var. medium derivatives on insects and of piperaceous derivatives on T. absoluta.

Due to the abundance of plant material at the collection site and the higher levels of mortality observed during screening, the leaf extract of $P$. amalago var. medium was considered as the main candidate for the development of a botanical insecticide for protection of horticultural crops in Brazil. Therefore, it was selected for further investigation.

Based on the results of the concentration-response curves, in which $\mathrm{LC}_{50}=1,011 \mathrm{mg} \mathrm{L}^{-1}$ (Table 2),

Table 1. Means \pm standard error of Tuta absoluta larval weight and mortality after six days of exposure to tomato (Solanum lycopersicum) leaflets treated with ethanolic leaf extracts from different Piperaceae species, at the concentration of $2,000 \mathrm{mg} \mathrm{L}^{-1(1)}$.

\begin{tabular}{|c|c|c|c|c|c|c|c|}
\hline \multirow[t]{2}{*}{ Plant species } & \multicolumn{5}{|c|}{ Mortality (\%) } & & \multirow{2}{*}{$\begin{array}{c}\text { Larval weight } \\
(\mathrm{mg})\end{array}$} \\
\hline & 24 hours & 48 hours & 72 hours & 96 hours & 120 hours & 144 hours & \\
\hline Piper amalago var. medium & $66.66 \pm 4.36 \mathrm{a}$ & $67.62 \pm 4.22 \mathrm{a}$ & $67.62 \pm 4.22 \mathrm{a}$ & $67.62 \pm 4.22 \mathrm{a}$ & $67.62 \pm 4.22 \mathrm{a}$ & $67.62 \pm 4.22 \mathrm{a}$ & $0.33 \pm 0.05$ \\
\hline Piper glabratum & $41.90 \pm 6.12 \mathrm{a}$ & $43.81 \pm 5.41 \mathrm{a}$ & $43.81 \pm 5.41 \mathrm{a}$ & $43.81 \pm 5.41 \mathrm{a}$ & $43.81 \pm 5.41 \mathrm{a}$ & $43.81 \pm 5.41 \mathrm{a}$ & $0.36 \pm 0.03$ \\
\hline Piper mikanianum & $50.47 \pm 7.81 \mathrm{a}$ & $50.48 \pm 7.82 \mathrm{a}$ & $50.48 \pm 7.82 \mathrm{a}$ & $50.48 \pm 7.82 \mathrm{a}$ & $50.48 \pm 7.82 \mathrm{a}$ & $50.48 \pm 7.82 \mathrm{a}$ & $0.24 \pm 0.04$ \\
\hline Piper mollicomum & $9.52 \pm 2.86 b$ & $11.43 \pm 2.80 \mathrm{~b}$ & $11.43 \pm 2.80 \mathrm{~b}$ & $11.43 \pm 2.80 \mathrm{~b}$ & $11.43 \pm 2.80 \mathrm{~b}$ & $11.43 \pm 2.80 \mathrm{~b}$ & $0.36 \pm 0.07$ \\
\hline Control & $9.40 \pm 2.87 \mathrm{~b}$ & $11.25 \pm 2.80 \mathrm{~b}$ & $11.25 \pm 2.80 \mathrm{~b}$ & $11.25 \pm 2.80 \mathrm{~b}$ & $11.25 \pm 2.80 \mathrm{~b}$ & $11.25 \pm 2.80 \mathrm{~b}$ & $0.32 \pm 0.03$ \\
\hline F value & $25.23 * *$ & $26.34 * *$ & $26.34 * *$ & $26.34 * *$ & $26.34 * *$ & $26.34 * *$ & $0.823^{\text {ns }}$ \\
\hline
\end{tabular}

${ }^{(1)}$ Means followed by different letters, in the columns, differ significantly among treatments according to the general linear model with quasi-binomial distri-

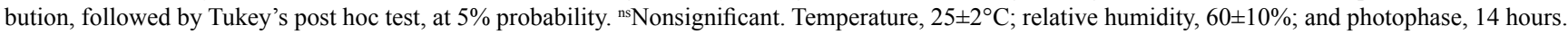

Table 2. Estimate of the concentrations $\left(\mathrm{mg} \mathrm{L}^{-1}\right)$ necessary to cause 50 and $90 \%$ mortality $\left(\mathrm{LC}_{50}\right.$ and $\mathrm{LC}_{90}$, respectively), as well as the confidence interval (CI) of the ethanolic leaf extract from Piper amalago var. medium against Tuta absoluta at different exposure times.

\begin{tabular}{|c|c|c|c|c|c|c|}
\hline $\begin{array}{l}\text { Exposure time } \\
\text { (hours) }\end{array}$ & $\mathrm{n}^{(1)}$ & $\begin{array}{c}\text { Slope } \pm \text { standard } \\
\text { error }\end{array}$ & $\mathrm{LC}_{50}(95 \% \mathrm{CI})$ & $\mathrm{LC}_{90}(95 \% \mathrm{CI})$ & $\begin{array}{c}\chi^{2(2)} \\
(\mathrm{df}=6)\end{array}$ & $\mathrm{h}^{(3)}$ \\
\hline 24 & 744 & $1.86 \pm 0.24 * *$ & $1,008(700.24-1,295)$ & $4,464(3,510-6,281)$ & 70.8 & 1.77 \\
\hline 48 & 744 & $1.87 \pm 0.25 * *$ & $1,011(688.79-1,311)$ & $4,440(3,475-6,303)$ & 73.91 & 1.84 \\
\hline 72 & 744 & $1.87 \pm 0.25 * *$ & $1,011(688.79-1,311)$ & $4,440(3,475-6,303)$ & 73.91 & 1.84 \\
\hline 96 & 744 & $1.87 \pm 0.25 * *$ & $1,011(688.79-1,311)$ & $4,440(3,475-6,303)$ & 73.91 & 1.84 \\
\hline 120 & 744 & $1.87 \pm 0.25 * *$ & $1,011(688.79-1,311)$ & $4,440(3,475-6,303)$ & 73.91 & 1.84 \\
\hline 144 & 744 & $1.87 \pm 0.25 * *$ & $1,011(688.79-1,311)$ & $4,440(3,475-6,303)$ & 73.91 & 1.84 \\
\hline
\end{tabular}

${ }^{(1)} \mathrm{n}$, number of insects tested. ${ }^{(2)} \chi^{2}$, Pearson's chi-square value. ${ }^{(3)} \mathrm{h}$, heterogeneity factor. Temperature, $25 \pm 2{ }^{\circ} \mathrm{C}$; relative humidity, $60 \pm 10 \%$; and photophase, 14 hours. **Significant at $1 \%$ of probability. 
there was no increase in mortality after 24 hours of exposure, according to the superimposition of the estimated confidence intervals. These results indicate that $T$. absoluta larval mortality occurs mainly in the period prior to leaf penetration, in particular via contact with the residue of the leaf extract. It was also observed that the caterpillars that had not penetrated the mesophyll after contact with the residue showed symptoms of lethargy and low mobility, which is likely associated with the mode of action of neurotoxins from piperaceous derivatives. The neurotoxic effects of Piperaceae extracts on insects have been described in other studies (Scott et al., 2005, 2007). Among the major classes of secondary compounds often found in species of the genus Piper, amides, lignans, alkaloids, and neolignans are highlighted. Amides, such as piperamides, commonly found in the genus Piper have dual biological activity on insects, including neurotoxic and lipid metabolism effects (Dyer \& Palmer, 2004). Effects of the knockdown type, with paralysis and immediate death of the insect, have also been reported in insects treated with amides isolated from Piperaceae species (Scott et al., 2007).

At the concentration of $1,011 \mathrm{mg} \mathrm{L}^{-1}\left(\mathrm{LC}_{50}\right)$, the ethanolic leaf extract from $P$. amalago var. medium

Table 3. Means \pm standard error of duration of the larval stage and of mortality of Tuta absoluta exposed to ethanolic leaf extract from Piper amalago var. medium at the previously-estimated concentration of $1,011 \mathrm{mg} \mathrm{L}^{-1}$, necessary to cause $50 \%$ mortality $\left(\mathrm{LC}_{50}\right)$.

\begin{tabular}{lcc}
\hline Treatment & $\begin{array}{c}\text { Duration } \\
(\text { days })^{(1)}\end{array}$ & $\begin{array}{c}\text { Mortality } \\
(\%)^{(2)}\end{array}$ \\
\hline Piper amalago var. medium & $11.22 \pm 0.17 \mathrm{a}$ & $32.05 \pm 4.88$ \\
Control (acetone) & $10.60 \pm 0.12 \mathrm{~b}$ & $19.17 \pm 6.09$ \\
\hline F value & $9.0888^{* *}$ & $2.3645^{\text {ns }}$ \\
\hline
\end{tabular}

(1) Means followed by different letters, in the column, differ significantly among treatments by the general linear model (GLM) with Gaussian distribution, followed by Tukey's post hoc test, at $5 \%$ probability. ${ }^{(2)}$ Means followed by different letters, in the column, differ significantly among treatments by the GLM with quasi-binomial distribution, followed by Tukey's post hoc test, at $5 \%$ probability. ${ }^{n}$ Nonsignificant. Temperature, $25 \pm 2{ }^{\circ} \mathrm{C}$; relative humidity, $60 \pm 10 \%$; and photophase, 14 hours. lengthened the larval and pupal stages of T. absoluta (Tables 3 and 4) but did not affect survival in this stage or larval weight. Unexpectedly, the level of mortality was lower than in the previous bioassay with concentration-response curves. This reduction may be related, in hypothesis, to variations in the nutritional composition of the tomato leaves (testing substrate) used in the different biossays or to differences in insect strength over the generations, factors that can affect the tolerance of the exposed insects to xenobiotic compounds (De Bruyn et al., 2002). Dyer et al. (2003) tested the effects of three Piper amides isolated from $P$. cenocladum on $S$. frugiperda and also observed a lengthening of the insect's development time. It should be noted that the elongation of a moth's life stages is a desirable effect because it can increase the time of exposure to natural enemies and the average time of each generation, reducing the population growth rate and minimizing crop damage.

The ethanolic leaf extract of $P$. amalago var. medium, at the concentration of $2,000 \mathrm{mg} \mathrm{L}^{-1}$, caused mortality in T. absoluta larvae of almost $70 \%$ and shows promise for the control of tomato leaf miner in small growing areas.

Table 4. Means \pm standard error of larval weight, mortality, and duration of pupal stage, as well as the sex ratio of emerged adults of Tuta absoluta exposed to ethanolic leaf extract from Piper amalago var. medium at the previously-estimated concentration of $1,011 \mathrm{mg} \mathrm{L}^{-1}$, necessary to cause $50 \%$ mortality $\left(\mathrm{LC}_{50}\right)$.

\begin{tabular}{lcccc}
\hline Treatment & $\begin{array}{c}\text { Weight } \\
(\mathrm{mg})^{(1)}\end{array}$ & $\begin{array}{c}\text { Mortality } \\
(\%)^{(2)}\end{array}$ & $\begin{array}{c}\text { Duration } \\
(\text { days })^{(3)}\end{array}$ & Sex ratio \\
\hline $\begin{array}{l}\text { Piper amalago } \\
\text { var. medium }\end{array}$ & $4.47 \pm 0.10$ & $5.83 \pm 3.30$ & $11.15 \pm 0.17 \mathrm{a}$ & $0.55 \pm 0.07$ \\
Control & $4.42 \pm 0.10$ & $12.32 \pm 3.46$ & $10.24 \pm 0.07 \mathrm{~b}$ & $0.51 \pm 0.05$ \\
\hline F value & $0.0973^{\text {ns }}$ & $0.304^{\text {ns }}$ & $23.705^{* *}$ & $\chi^{2}=24.751^{\text {ns }}$ \\
\hline
\end{tabular}

(1)No significant differences by the general linear model (GLM) with Gaussian distribution, at $5 \%$ probability. ${ }^{(2)}$ No significant differences by the GLM with a quasi-binomial distribution, at $5 \%$ probability. ${ }^{(3)}$ Means followed by different letters, in the column, do not differ significantly by the GLM with Gaussian distribution, followed by Tukey's post hoc test, at 5\% probability. ${ }^{(4)}$ No significant differences by the GLM with a binomial distribution, at $5 \%$ probability. ${ }^{n}$ Nonsignificant. Temperature, $25 \pm 2{ }^{\circ} \mathrm{C}$; relative humidity, $60 \pm 10 \%$; and photophase, 14 hours. 


\section{Conclusions}

1. Ethanolic leaf extracts, at the concentration of 2,000 $\mathrm{mg} \mathrm{L}^{-1}$, from Piper amalago var. medium, $P$. glabratum, and $P$. mikanianum have insecticidal activity against Tuta absoluta larvae, although none of them reduce the weight (growth inhibition) of the surviving larvae.

2. The ethanolic leaf extract from $P$. amalago var. medium causes a significant lengthening of the development time of the larval and pupal stages of $T$. absoluta.

\section{Acknowledgments}

To Conselho Nacional de Desenvolvimento Científico e Tecnológico (CNPq), for financial support; to Dr. Vitor O. Becker from Instituto Uiraçu, for confirmation of the studied pest species; and to Dr. Elsie Franklin Guimarães from Jardim Botânico do Rio de Janeiro, for the identification of the Piperaceae species.

\section{References}

ALVES, T.J.S.; CRUZ, G.S.; WANDERLEY-TEIXEIRA, V.; TEIXEIRA, A.A.C.; OLIVEIRA, J.V.; CORREIA, A.A.; CÂMARA, C.A.G.; CUNHA, F.M. Effects of Piper hispidinervum on spermatogenesis and histochemistry of ovarioles of Spodoptera frugiperda. Biotechnic and Histochemistry, v.89, p.245-255, 2014. DOI: $10.3109 / 10520295.2013 .837509$.

BRASIL. Ministério da Agricultura, Pecuária e Abastecimento. Decreto $n^{\circ} 6.913$ de 23 de julho de 2009. Dispõe sobre a pesquisa, a experimentação, a produção, a embalagem e rotulagem, o transporte, o armazenamento, a comercialização, a propaganda comercial, a utilização, a importação, a exportação, o destino final dos resíduos e embalagens, o registro, a classificação, o controle, a inspeção e a fiscalização de agrotóxicos, seus componentes e afinsa. Diário Oficial [da] República Federativa do Brasil, 24 jul. 2009. Seção 1, p.8.

CAMPOS, M.R.; RODRIGUES, A.R.S.; SILVA, W.M.; SILVA, T.B.M.; SILVA, V.R.F.; GUEDES, R.N.C.; SIQUEIRA, H.A.A. Spinosad and the tomato borer Tuta absoluta: a bioinsecticide, an invasive pest threat, and high insecticide resistance. Plos One, v.9, e103235, 2014. DOI:10.1371/journal.pone.0103235.

CANTRELL, C.L.; DAYAN, F.E.; DUKE, S.O. Natural products as sources for new pesticides. Journal of Natural Products, v.75, p.1231-1242, 2012. DOI: 10.1021/np300024u.

DE BRUYN, L.; SCHEIRS, J.; VERHAGEN, R. Nutrient stress, host plant quality and herbivore performance of a leaf-mining fly on grass. Oecologia, v.130, p.594-599, 2002. DOI: 10.1007/ s00442-001-0840-1.
DEBONSI, H.M.; MIRANDA, J.E.; MURATA, A.T.; DE BORTOLI, S.A.; KATO, M.J.; BOLZANI, V.S.; FURLAN, M. Isobutyl amides-potent compounds for controlling Diatraea saccharalis. Pest Management Science, v.65, p.47-51, 2008. DOI: $10.1002 / \mathrm{ps} .1643$.

DESNEUX, N.; WAJNBERG, E.; WYCKHUYS, K.A.G.; BURGIO, G.; ARPAIA, S.; NARVÁEZ-VASQUEZ, C.A.; GONZÁLEZ-CABRERA, J.; RUESCAS, D.C.; TABONE, E.; FRANDON, J.; PIZZOL, J.; PONCET, C.; CABELLO, T.; URBANEJA, A. Biological invasion of European tomato crops by Tuta absoluta: ecology, geographic expansion and prospects for biological control. Journal of Pest Science, v.83, p. 197-215, 2010. DOI: $10.1007 / \mathrm{s} 10340-010-0321-6$.

DYER, L.A.; DODSON, C.D.; STIREMAN III, J.O.; TOBLER, M.A.; SMILANICH, A.M.; FINCHER, R.M.; LETOURNEAU, D.K. Synergistic effects of three Piper amides on generalist and specialist herbivores. Journal of Chemical Ecology, v.29, p.2499-2514, 2003. DOI: 10.1023/A:1026310001958.

DYER, L.A.; PALMER, A.D.N. Piper: a model genus for studies of phytochemistry, ecology and evolution. New York: Kluwer Academic: Plenum Publishers, 2004. 228p. DOI: 10.1007/978-0-387-30599-8.

EUROPEAN AND MEDITERRANEAN PLANT PROTECTION ORGANIZATION. Tuta absoluta: data sheets on quarantine pests. Bulletin OEPP/EPPO, v.35, p.434-435, 2005.

FINNEY, D.J. Probit analysis. Cambridge: Cambridge University, 1971.31p.

HADDI, K.; BERGER, M.; BIELZA, P.; CIFUENTES, D.; FIELD, L.M.; GORMAN, K.; RAPISARDA, C.; WILLIAMSON, M.S.; BASS, C. Identification of mutations associated with pyrethroid resistance in the voltage-gated sodium channel of the tomato leaf miner (Tuta absoluta). Insect Biochemistry and Molecular Biology, v.42, p.506-513, 2012. DOI: 10.1016/j.ibmb.2012.03.008.

HINDE, J.; DEMÉTRIO, C.G.B. Overdispersion: models and estimation. Computational Statistics and Data Analysis, v.27, p.151-170, 1998. DOI: 10.1016/S0167-9473(98)00007-3.

KITAYAMA, T.; YASUDA, K.; KIHARA, T.; ITO, M.; FUKUMOTO, H.; MORIMOTO, M. Piperine analogs in a hydrophobic fraction from Piper ribersoides (Piperaceae) and its insect antifeedant activity. Applied Entomology and Zoology, v.48, p.455-459, 2013. DOI: 10.1007/s13355-013-0204-4.

LIETTI, M.M.M.; BOTTO, E.; ALZOGARAY, R.A. Insecticide resistance in Argentine populations of Tuta absoluta (Meyrick) (Lepidoptera: Gelechiidae). Neotropical Entomology, v.34, p.113-119, 2005. DOI: 10.1590/S1519-566X2005000100016.

MORGAN, E.D. The place of neem among modern natural pesticides. In: KOUL, O.; WAHAB, S. (Ed.). Neem: today and in the New Millennium. Dordrecht: Kluwer Academic, 2004. p.21-32. DOI: 10.1007/1-4020-2596-3_2.

MURILLO, M.C.Á.; SUAREZ, L.E.C.; SALAMANCA, J.A.C. Actividad insecticida sobre Spodoptera frugiperda (Lepidoptera: Noctuidae) de los compuestos aislados de la parte aérea de Piper septuplinervium (Miq.) c. dc. y las inflorescencias de Piper subtomentosum Trel. \& Yunck. (Piperaceae). Química Nova, v.37, p.442-446, 2014. DOI: 10.5935/0100-4042.20140067. 
NAVICKIENE, H.M.D.; MIRANDA, J.E.; BORTOLI, S.A.; KATO, M.J.; BOLZANI, V.S.; FURLAN, M. Toxicity of extracts and isobutyl amides from Piper tuberculatum: potent compounds with potential for the control of the velvetbean caterpillar, Anticarsia gemmatalis. Pest Management Science, v.63, p.399-403, 2007. DOI: $10.1002 /$ ps.1340.

NELDER, J.A.; WEDDERBURN, R.W.M. Generalized linear models. Journal of the Royal Statistical Society Series A-General, v.135, p.370-384, 1972. DOI: 10.2307/2344614.

PHILOGÈNE, B.J.R.; VINCENT, C. Botanicals: yesterday's and today's promises. In: REGNAULT-ROGER, C.; PHILOGÈNE, B.J.R.; VINCENT, C. (Ed.). Biopesticides of plant origin, 2005. p.1-15.

QU, H.; YU, X.; ZHI, X.; LV, M.; XU, H. Natural-product-based insecticidal agents 14 . Semisynthesis and insecticidal activity of new piperine-based hydrazone derivatives against Mythimna separata Walker in vivo. Bioorganic and Medicinal Chemistry Letters, v.23, p.5552-5557, 2013. DOI: 10.1016/j.bmcl.2013.08.053.

R DEVELOPMENT CORE TEAM. R: a language and environment for statistical computing. Vienna: R Foundation for Statistical Computing, 2012.

RIBEIRO, L.P.; VENDRAMIM, J.D.; ANDRADE, M.S.; BICALHO, K.U.; SILVA, M.F.G.F.; VIEIRA, P.C.; FERNANDES, J.B. Tropical plant extracts as sources of grain-protectant compounds against Sitophilus zeamais Motschulsky (Coleoptera: Curculionidae). Neotropical Entomology, v.43, p.470-482, 2014. DOI: $10.1007 / \mathrm{s} 13744-014-0233-\mathrm{x}$.

RODITAKIS, E.; SKARMOUTSOU, C.; STAURAKAKI, M. Toxicity of insecticides to populations of tomato borer Tuta absoluta (Meyrick) from Greece. Pest Management Science, v.69, p.834-840, 2013. DOI: 10.1002/ps.3442.

RODITAKIS, E.; VASAKIS, E.; GRISPOU, M.; STAVRAKAKI, M.; NAUEN, R.; GRAVOUIL, M.; BASSI, A. First report of
Tuta absoluta resistance to diamide insecticides. Journal of Pest Science, v.8, p.9-16, 2015. DOI: 10.1007/s10340-015-0643-5.

SCOTT, I.M.; GAGNON, N.; LESAGE, L.; PHILOGÈNE, B.J.R.; ARNASON, J.T. Efficacy of botanical insecticides from Piper species (Piperaceae) extracts for control of European chafer (Coleoptera: Scarabaeidae). Journal of Economic Entomology, v.98, p.845-855, 2005. DOI: 10.1603/0022-0493-98.3.845.

SCOTT, I.M.; HELSON, B.V.; STRUNZ, G.M.; FINLAY, H.; SÁNCHEZ-VINDAS, P.E.; POVEDA, L.; LYONS, D.B.; PHILOGÈNE, B.J.R.; ARNASON, J.T. Efficacy of Piper nigrum (Piperaceae) extract for control of insect defoliators of forest and ornamental trees. The Canadian Entomologist, v.139, p.513-522, 2007. DOI: $10.4039 /$ n06-040.

SCOTT, I.M.; JENSEN, H.; NICOL, R.; LESAGE,L.; BRADBURY, R.; SANCHEZ-VINDAS, P.; POVEDA, L.; ARNASON, J.T.; PHILOGÈNE, B.J.R. Efficacy of Piper (Piperaceae) extracts for control of common home and garden insect pests. Journal of Economic Entomology, v.97, p.1390-1403, 2004. DOI: 10.1093/ jee/97.4.1390.

SCOTT, I.M.; JENSEN, H.R.; PHILOGÈNE, B.J.; ARNASON, J.T. A review of Piper spp. (Piperaceae) phytochemistry, insecticidal activity and mode of action. Phytochemistry Reviews, v.7, p.65-75, 2008. DOI: 10.1007/s11101-006-9058-5.

SILVA, G.A.; PICANÇO, M.C.; BACCI, L.; CRESPO, A.L.B.; ROSADO, J. F.; GUEDES, R.N.C. Control failure likelihood and spatial dependence of insecticide resistance in the tomato pinworm, Tuta absoluta. Pest Management Science, v.67, p.913-920, 2011. DOI: $10.1002 /$ ps.2131.

SOUZA, J.C. de; REIS, P.R. Traça-do-tomateiro: histórico, reconhecimento, biologia, prejuízo e controle. 3.ed. Belo Horizonte: EPAMIG, 2000. 32p. (Boletim técnico, 57).

YUNCKER, T.G. The Piperaceae of Brazil IV: index. Hoehnea, v.5, p.123-145, 1975.

Received on August 11, 2014 and accepted on February 23, 2015

Pesq. agropec. bras., Brasília, v.50, n.3, p.196-202, mar. 2015

DOI: 10.1590/S0100-204X2015000300002 